\title{
Coronavirus Disease - 2019 (COVID-19) İlişkili Makrofaj Aktivasyon Sendromu Tanısı Konulan Vakada Tocilizumab Deneyimi ve İmmünopatogenez Bakış
}

\author{
Cornavirus Disease - 2019 (COVID-19) Tocilizumab Experience \\ and Immunopathogenesis in a Case That Has Been Diagnosed
}

Burak OKYAR ${ }^{1}$, Gihan YEŞİL ${ }^{2}$

${ }^{1}$ Osmaniye Devlet Hastanesi, İç Hastalıkları Departmanı

${ }^{2}$ Osmaniye Devlet Hastanesi, Enfeksiyon Hastalıkları ve Klinik Mikrobiyoloji Departmanı

Yazışma Adresi

Correspondence Address

\section{Burak OKYAR}

Osmaniye Devlet Hastanesi, İç Hastalıkları Departmanı, Türkiye

E-posta: okyarmd@gmail.com, drcihanyesil@gmail.com
Geliş tarihi \ Received : 07.05 .2020 Kabul tarihi \ Accepted : 12.08.2020 Elektronik yayın tarihi $\quad: 12.07 .2021$ Online published

Bu makaleye yapılacak atıf: Cite this article as:

Okyar B, Yeşil C. Coronavirus disease - 2019 (COVID-19) ilişkili makrofaj aktivasyon sendromu tanısı konulan vakada tocilizumab deneyimi ve immünopatogenez bakış. Akd Tıp D $2021 ; 7(2): 323-330$

Burak OKYAR ORCID ID: 0000-0002-9028-9930 Cihan YEŞİ ORCID ID: 0000-0003-3558-5689

\section{ÖZ}

Makrofaj aktivasyon sendromu (MAS) herediter veya akkiz olarak gelişebilen, yaygın bulgular verebilen ve tanısının konulması kimi zaman güç olan klinik bir sendromdur. Tüm dünyayı etkisi altına alan coronavirus disease-2019 (COVID-19) ve buna sekonder gelişen pnömoni, ciddi ve fatal seyredebilen bir komplikasyondur. Hastalığın seyrinde ölümcül sonuçlar doğurabilecek sekonder MAS gelişebilmektedir ve klinik olarak erken tanı konulması tedavi stratejisini değiştirmekte ve sonuç olarak hastalık seyrini yavaşlatıp durdurabilmektedir. Osmaniye Devlet Hastanesi'nde takip edilen COVID-19 tanılı hastada klinik ve laboratuvar değerleri yakın takip edilerek sekonder MAS tanısı konularak, tocilizumab (TCL) tedavisi verildi ve sonrasında klinik ve laboratuvar parametrelerinin seyri takip edildi. Bu tek vaka üzerinden klinik, laboratuvar ve görüntülemedeki değişiklikleri tartıştık.

Anahtar Sözcükler: COVID-19, Makrofaj aktivasyon sendromu, Tocilizumab

\begin{abstract}
Macrophage activation syndrome (MAS) is a clinical syndrome that can develop hereditary and acquired, can give widespread findings and is sometimes difficult to diagnose. Coronavirus disease-2019 (COVID-19), which affects the whole world, and secondary pneumonia is a serious and fatal complication. Secondary MAS can develop that can have fatal outcomes in the course of the disease, and early diagnosis of the clinic changes the treatment strategy and consequently slows down the course of the disease. In the patient diagnosed with COVID-19, which was followed up in Osmaniye State Hospital, tocilizumab (TCL) treatment was given by following the diagnosis of secondary MAS, following the clinical and laboratory values, and then the course of the clinical and laboratory parameters were followed. We discussed the changes in clinical, laboratory and imaging through this single case.
\end{abstract}

Keywords: COVID-19, Macrophage activation syndrome, Tocilizumab

\section{Gİiş}

Severe acute respiratory syndrome coronavirus-2 (SARS-CoV2), 11 Mart 2020 tarihinde Dünya Sağlık Örgütü (DSÖ) pandemi olarak ilan edilen COVID-19'un etkenidir. Wuhan'da COVID-19 tanısı alan 1099 hastayı kapsayan bir çalışmada, hastalığın başlangıcında en sık görülen klinik semptomlar: \%88’inde ateş, \%76'sinde kuru öksürük, \%38’inde yorgunluk, \%14,9'unda myalji (kas ağrısi), \%18,7'sinde dispne'dir. Pnömoni, enfeksiyonun en yaygın ve şiddetli belirtisidir. Bu hasta grubunda ortalama beş günlük hastalıktan sonra solunum güçlügü gelişmiştir. Hastaların \% 3,4'ünde akut solunum sıkıntısı sendromu (ARDS) gelişmiştir (1). COVID-19 tanılı vakaların yaklaşık \%80’inde hafif ya da orta derecede hastalık 
görülmekte iken \%13'ünde şiddetli hastalık görülmektedir (dispne, solunum sayısı $\geq 30 /$ dakika, kan oksijen satürasyonu $\leq 93 \%, \mathrm{PaO} 2 / \mathrm{FiO} 2$ oranı $<300,24-48$ saat içinde $\% 50$ 'den fazla akciğer tutulumu). Kritik hastalık (solunum yetmezliği, septik şok, çoklu organ fonksiyon bozukluğu) vakaların sadece $\% 6$ 'sından azında görülmektedir (1).

Makrofaj aktivasyon sendromu/hemofagositik lenfohistiositoz (MAS/HLH) tek bir hastalığın değil, farklı durumların aynı tipte inflamatuvar yanıt fenotipini oluşturduğu bir klinik sendromu temsil eder. Akkiz veya herediter olabilir. Temel mekanizma sitotoksik T-lenfositler ve natural killer (NK) hücrelerin fonksiyonlarında bozulma, makrofaj ve T-lenfositlerin aktivasyonu, proinflamatuvar sitokinlerin aşırı üretimi ve hemofagositoz sonucu ateş, hepatosplenomegali ve sitopeninin ön planda olduğu klinik tablo ile karakterizedir (2,3). COVID-19 sekonder MAS ise bu tablodan biraz daha farklıdır. GOVID-19 ilişkili MAS'ın daha çok pulmoner hasar yaptığı ve organomegalinin olmadığ görülmüşür. Yapılan çalışmalarda bölgesel olarak intrapulmoner vasküler mikrotrombüs, fibrinolizis ve hemoraji yapmaya eğilimli olduğu görülmüştür. COVID-19 ilişkili MAS'ta erken dönemde D-dimer yüksekliği görülmesi ve pulmoner infiltrasyon ve hasarm pulmoner vasküler dağılımı ile paralellik göstermesi, bu bölgesel inflamatuvar yanıtın bir sonucudur (4). Yapılan çalışmalarda C-reaktif protein (CRP) ve ferritin yüksekliği, lenfopeni, karaciğer fonksiyon testi (KCFT) bozukluğu ve koagülopatinin COVID-19'a sekonder MAS'a gidişte önemli bir uyarıcı olduğu görülmüştür (5). Tedaviye rağmen devam eden dirençli ateş, devamlı yüksek seyreden ya da artmaya devam eden CRP ve ferritin değerleri, D-dimer yüksekliği, lenfopeni ve trombositopeni şeklinde sitopeniler, karaciğer fonksiyon testlerinde bozulma, hipofibrinojenemi gibi bulguların varlığı hastalık seyrinde MAS tablosunun geliştiğini düşündürür $(6,7)$.

Akut respiratuvar distres sendromu (ARDS) gelişen hastalarda bazal plazma interlökin-6 (IL-6) seviyesinin kötü prognozu gösterdiği uzun zamandır bilinen bir gerçektir (8). COVID-19 ilişkili pulmoner hasar ve ARDS tablosuna gidişte viral immünsupresyonun bir parçası olan lenfopeni ve buna sekonder gelişen interferon gama (IFN-gama) düzeyinin supresyonu ile ilişkili olduğu düşünülmektedir. Yapılan sınırlı sayıdaki çalışmada hastalık şiddetinin CD4+T-lenfositlerinin düşük IFN-gama üretimi ile ters ilişkili olduğu gösterilmiştir (9).

COVID-19 hastalığının seyrinde ilk antiviral defansın kaybedilmesi ile ikinci dalga oluşmaktadır. Bu ikinci dalgada IL-6 üretimi artmakta ve sonuç olarak non-tip 1 interferon yolu aktive olmaktadır. Bu kaskatın sonucunda IL-1, TNF, IL-18, GM-CSF gibi proinflamatuar sitokinler salınmakta ve sonuç olarak sitokin firtınası ve MAS tablosu oluşmaktadır. MAS tablosuna gidişte ise viral yük büyük önem arz etmektedir. Serum viral RNA yükü ile ARDS ciddiyeti arasında çok yakın bir korelasyon olduğu çalışmalarda gösterilmiştir (10). Laboratuvar parametrelerinde bakılan CRP, ferritin, lenfosit düzeyi bize viral yük, ARDS tablosuna gidiş ve seçilecek tedavi hakkında fikir verebilir. D-dimer düzeyi ise gelişmekte olan bir MAS tablosunun habercisi olabilir. Yapılan çalışmalarda sitokin firtınasının ortasında bulunan IL-6'nın bloke edilmesinin COVID-19'a sekonder MAS'ta faydalı olduğu gösterilmiştir (6,7). Bu yazıda COVID-19'a sekonder MAS tanısı koyulan olguda tocilizumab tedavisi sonrası, laboratuvar parametreleri ve görüntülemelerdeki değişimler incelenmiş̧î.

\section{OLGU SUNUMU}

52 yaşında bilinen kronik hastalığı olmayan erkek hasta, öksürük ve nefes darlığı ile başvurdu. Öyküsünde doğrulanmış COVID-19 vakası ile yakın temas vardı. Parmaktan ölçülen pulse oksimetre oksijen saturasyonu \%65 idi. Nabız 88/dakika (dk), solunum sayısı 24/dk, ateş $37.1{ }^{\circ} \mathrm{C}$ , arteriyel tansiyon 110/90 mmHg idi. Fizik muayenesinde, solunum sesleri kaba ve her iki akciğer bazallerde dinlemekle ralleri mevcut idi. Sistemik muayenesi haricen normaldi. Gönderilen rutin tetkiklerinde lökosit sayısı: $10.7310^{3} / \mu \mathrm{l}$, hemoglobin: $13.5 \mathrm{~g} / \mathrm{dL}$, lenfosit sayıs1: 1.00 10^/L, trombosit sayısı: $21410^{3} / \mu \mathrm{l}$, D-Dimer: $0.9 \mu \mathrm{g} /$ $\mathrm{mL}$, C-reaktif protein: $71.5 \mathrm{mg} / \mathrm{L}$, kreatinin: $0.9 \mathrm{mg} /$ dL, aspartat aminotransferaz (AST): $82.5 \mathrm{U} / \mathrm{L}$, alanin aminotransferaz (ALT): 143.6 U/L olarak geldi. Hastaya yapılan kontrastsız bilgisayarlı tomografide (BT) (Şekil-la, 2a, 3a) bilateral akciğerlerde orta ve alt segmentlerde daha belirgin olmak üzere, ağırlıklı olarak periferik dağglımlı buzlu cam dansite alanları görülmektedir. Yer yer eşlik eden konsolidasyon sahaları görülmüştür. Hasta yoğun bakımımıza yatırılarak hidroksiklorokin ( 2x400 mg yükleme, 2x200 mg idame) ve favipravir (2x1600 mg yükleme, 2x600 mg idame) başlandı. Takip eden süreçte hastanın ateşi düşmedi, oksijen saturasyonu 6 litre/dk'dan verilmesine rağmen \%88 üzerine çıkmadı. Hastanın bakılan laboratuvar parametrelerinde lenfopeninin derinleşmesi, CRP'nin yükselmesi D-dimer'in yükselmesi ve KCFT'de bozulma olması üzerine hastada MAS düşünüldü ve IL-6 düzeyi gönderildi. Lenfoadenopati muayenesinde herhangi bir bulgu saptanmadı. Yapilan abdominal ultrasonografide herhangi bir organomegali yoktu. IL-6 düzeyinin 45.3 $\mathrm{pg} / \mathrm{mL}$ (normal aralık 0 - 5,9), gelmesi üzerine hastaya 4. günde T.C Sağlık Bakanlığı COVID-19 antisitokin tedavi rehberine uygun olarak Tocilizumab (TCL) 1. gün $400 \mathrm{mg}$ ve ikinci gün $400 \mathrm{mg}$, toplamda $800 \mathrm{mg}$ uygulandı (11). TCL sonrası laboratuvar parametrelerinde anlamlı bir gerileme saptandı. Hastalığın seyrinde prognostik önemi gösterilmiş olan D-dimer (Grafik-1), AST (Grafik-3), ALT (Grafik-4), Ferritin (Grafik-5), CRP (Grafik-6) düzeylerinde düşüş ve lenfosit sayısında yükselme (Grafik-2) saptandı. 

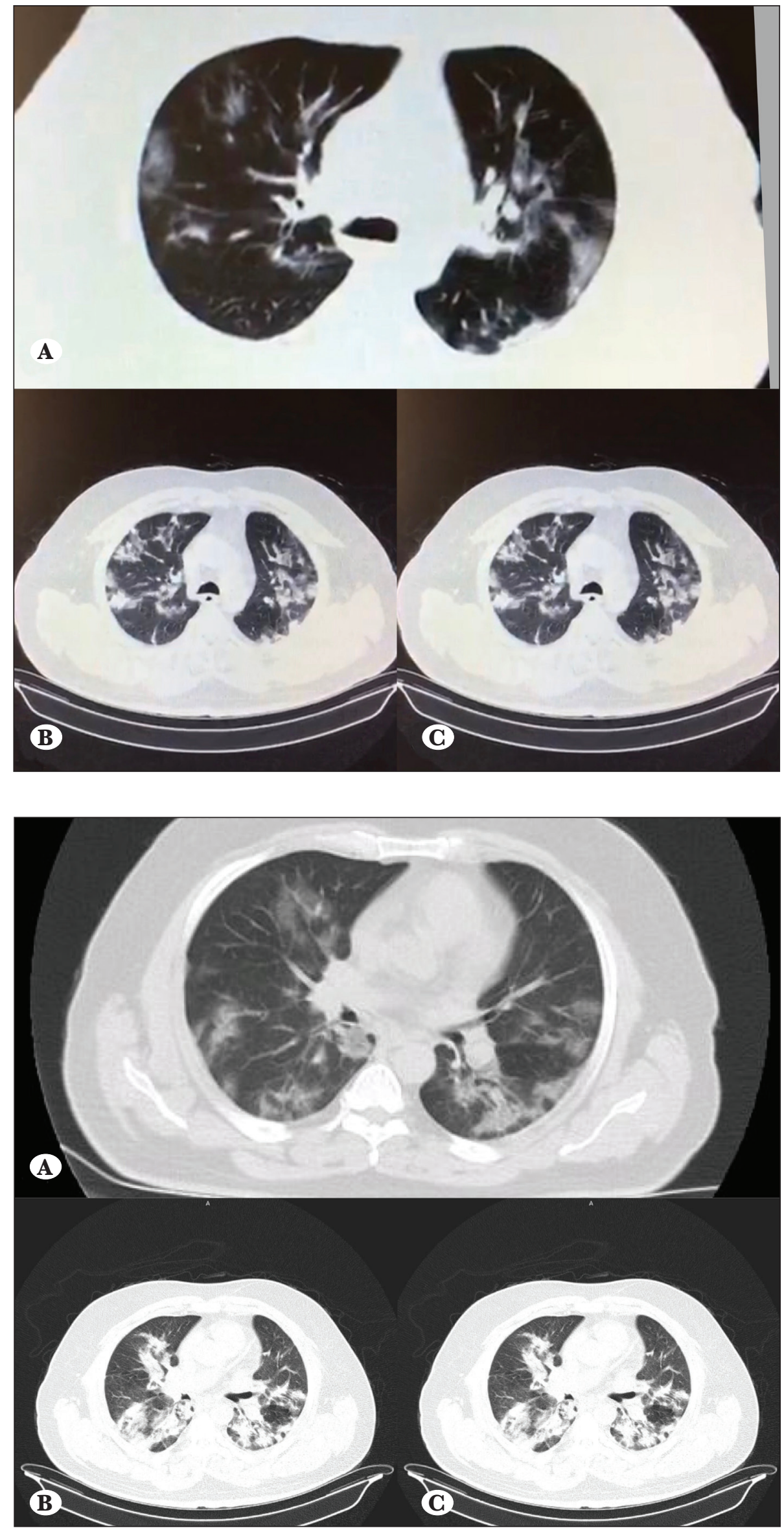

Şekil 1: A) Üst segment görüntülerinde bilateral ve periferik dağılımlı buzlu cam dansite alanları görülmekte.

B) Üst segment görüntülerinde bilateral ve periferik dağılımlı yer yer birleşme eğiliminde yamasal konsolidasyon alanları görülmekte olup bir önceki tomografiye göre progresyon görülmektedir.

C) Üst segment görüntüsünde bilateral periferik dağglımlı yamasal konsolidasyon alanlarında regresyon görülmektedir.
Şekil 2: A) Orta segment görüntüsünde bilateral ve periferik dağ̣lımlı buzlu cam dansite alnaları üst segmente göre çok daha yoğun şekilde görülmektedir.

B) Orta segment görüntüsünde periferik dağılıml, birleşme eğiliminde yamasal konsolidasyon alanları ve subplevral bant formasyonları görülmektedir.

G) Orta segment görüntüsünde yamasal konsolidasyon alanlarında belirgin regresyon görülmektedir. 


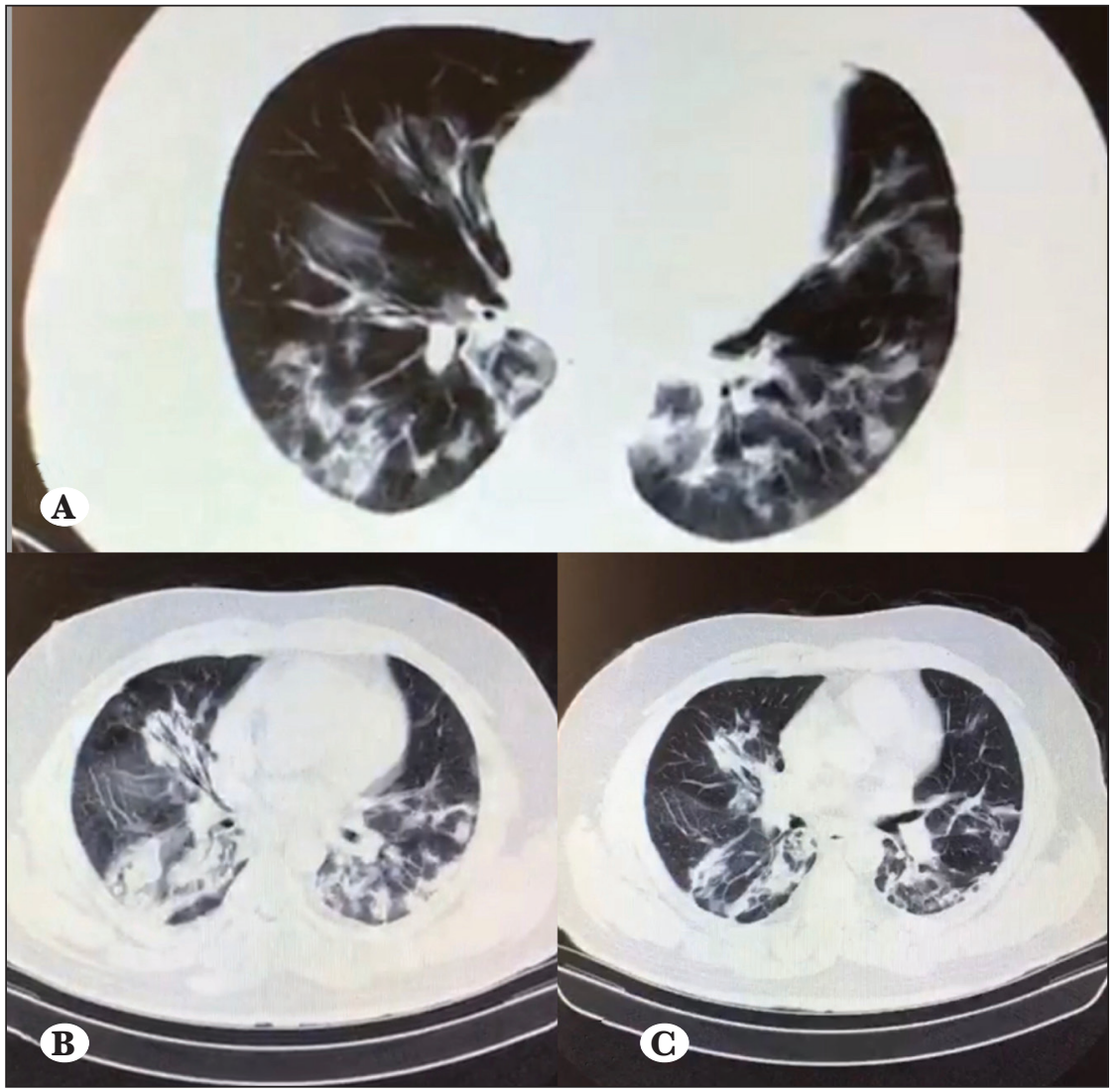

Şekil 3: A) Alt segment görüntüsünde bilateral ve periferik dağılımlı buzlu cam dansite alanları orta segmentte görüldüğü kadar yoğun şekilde görülmektedir. B) Alt segment görüntüsünde yamasal konsolidasyon alanları görülmektedir. C) Alt segment görüntüsünde yamasal konsolidasyon alanlarında belirgin regresyon görülmektedir.
TCL sonrası hastanın 7. gününde ikinci bir BT görüntüleme istenildi (Şekil-1b, 2b, 3b). Hastanın görüntülemesinde bilateral akciğerlerde orta ve alt segmentlerde daha belirgin olmak üzere periferik dağılıml, yer yer birleşme eğiliminde, yamasal konsolidasyon alanları izlenmekte ayrıca subplevral bant formasyonları görülmektedir. 17. gününde çekilen 3. kontrastsız BT'sinde (Şekil-1c, 2c, 3c) önceki incelemeler ile karşılaştırmalı değerlendirildiğinde, yamasal konsolidasyon alanlarında belirgin regresyon izlendi. Buzlu cam alanlarının kaybolduğu ve konsolidasyonun gerilediği görüldü. Hasta, yatışının 21. gününde oksijen ihtiyacının kalmaması, ateşinin olmaması klinik olarak düzelmesi üzerine taburcu edildi.

\section{SONUÇ}

Tocilizumab (TCL), çözünür ve membrana bağlı interlökin 6 reseptörlerine (IL-6R) yönelik immünoglobulin G1k alt sınıfinın rekombinant insanlaştırılmış, monoklonal bir antikorudur (12). TCL ilk olarak 2005 yilında Japonya'da nadir bir lenfoproliferatif hastalık olan Castleman hastalığının tedavisi için yetim bir ilaç olarak onaylandı (13). TCZ, IL-6'nın reseptörlerine bağlanmasını engeller, bunu yaparak insan IL-6 reseptörünün (IL-6R) hem çözünür hem de membrana bağlı formlarıla rekabet ederek bu sitokinin pro-enflamatuar aktivitesini azaltır (14). IL-6 reseptör antagonisti tocilizumab, COVID-19 dahil olmak üzere sekonder MAS olan hastalarda başarıyla kullanılmıştır $(15,16)$.
Yapılan çalışmalarda COVID-19 seyrinde bazı laboratuvar değerlerinin prognozu göstermede etkili olduğu gösterilmiştir. Özellikle D-dimer, lenfosit, ferritin, CRP, AST ve ALT değerlerinin yakın takibi, hastalığın seyrinde fikir vermektedir $(17,18)$. COVID-19 ile takip edilen hastalarda bu laboratuvar değerlerinin yakın takibi olası bir sitokin firtınasını öngörmek ve erken tedavi endikasyonunu belirlemek açısından değerlidir. Yapılan çalışmalarda COVID-19 sekonder MAS'ın klasik MAS'tan farklı olduğu görülmüştür (4). COVID-19'a sekonder MAS pulmoner hasar yapmaya meyilli olup altta yatan temel patolojinin intrapulmoner vasküler inflamasyon, mikrotrombüs ve hemoraji olduğu görülmüştür. Bu patolojinin altında yatan sebebin ise tetiklenen sitokin firtınası olduğu düşünülmektedir (4). Bu sitokin firtınasının ortasında ise IL-6 bulunmaktadır. Bu temel immünopatolojiden yola çıkarak, IL-6 antagonisti ilaçların hastalığın seyrini etkilediği ve sitokin firtınasını basklladığ çalışmalarda gösterilmiştir (6,7). GOVID-19 ilişkili MAS'ta erken tanı, tedavi açısından çok önemlidir. Zira ilerlemiş bir sitokin firtınasını baskılamak ve vereceği hasarı durdurmak çok daha zordur. Bizim hastamızda yapılan yakın klinik ve laboratuvar takibi sonrasında tedaviye rağmen dirençli ateşinin olması, KCFT bozukluğu gelişmesi, lenfopeni gelişmesi, tedrici olarak D-dimer düzeyinin artması ve ferritin değerlerinin artması COVID-19 ilişkili MAS tanısına yönlendirmiştir. Bakılan IL-6 düzeyinin yüksek gelmesi üzerine hastaya TCL tedavisi başlandı ve takiple- 


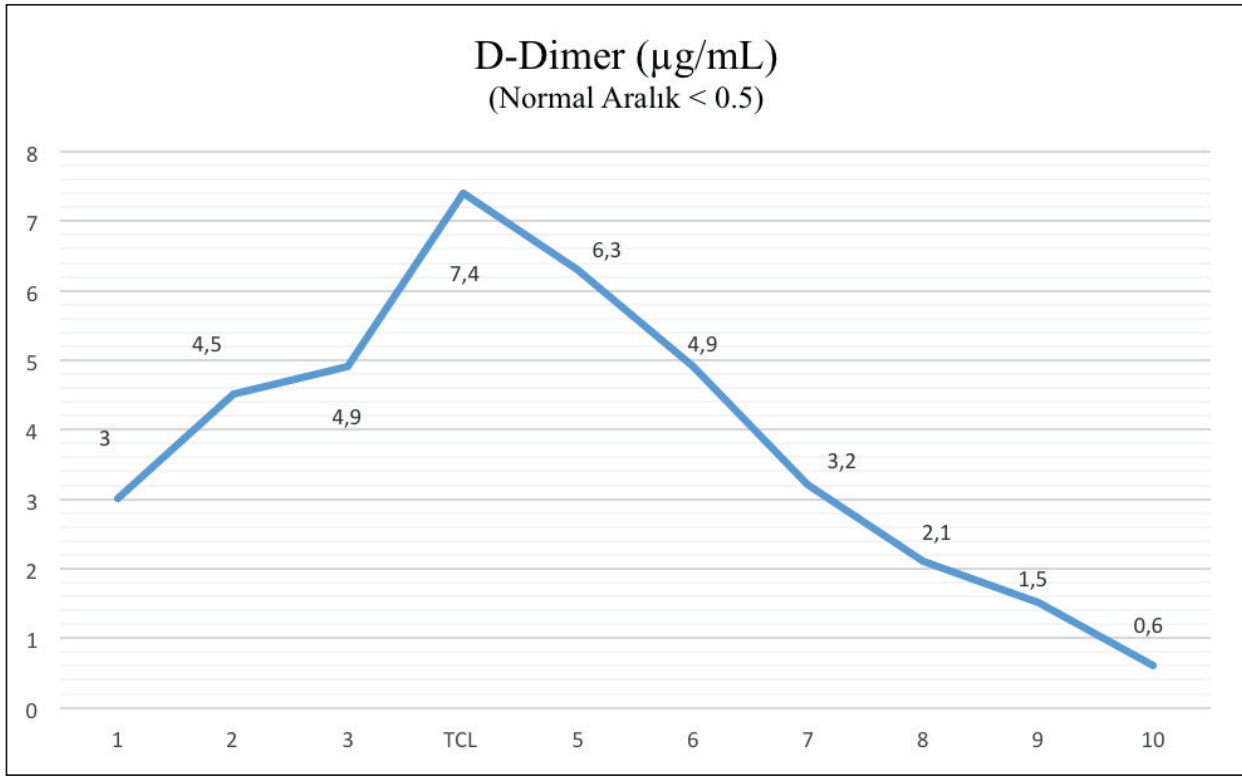

Lenfosit $\left(10^{\wedge} / \mathrm{L}\right)$

(Normal Aralık: 1.12-3.33)
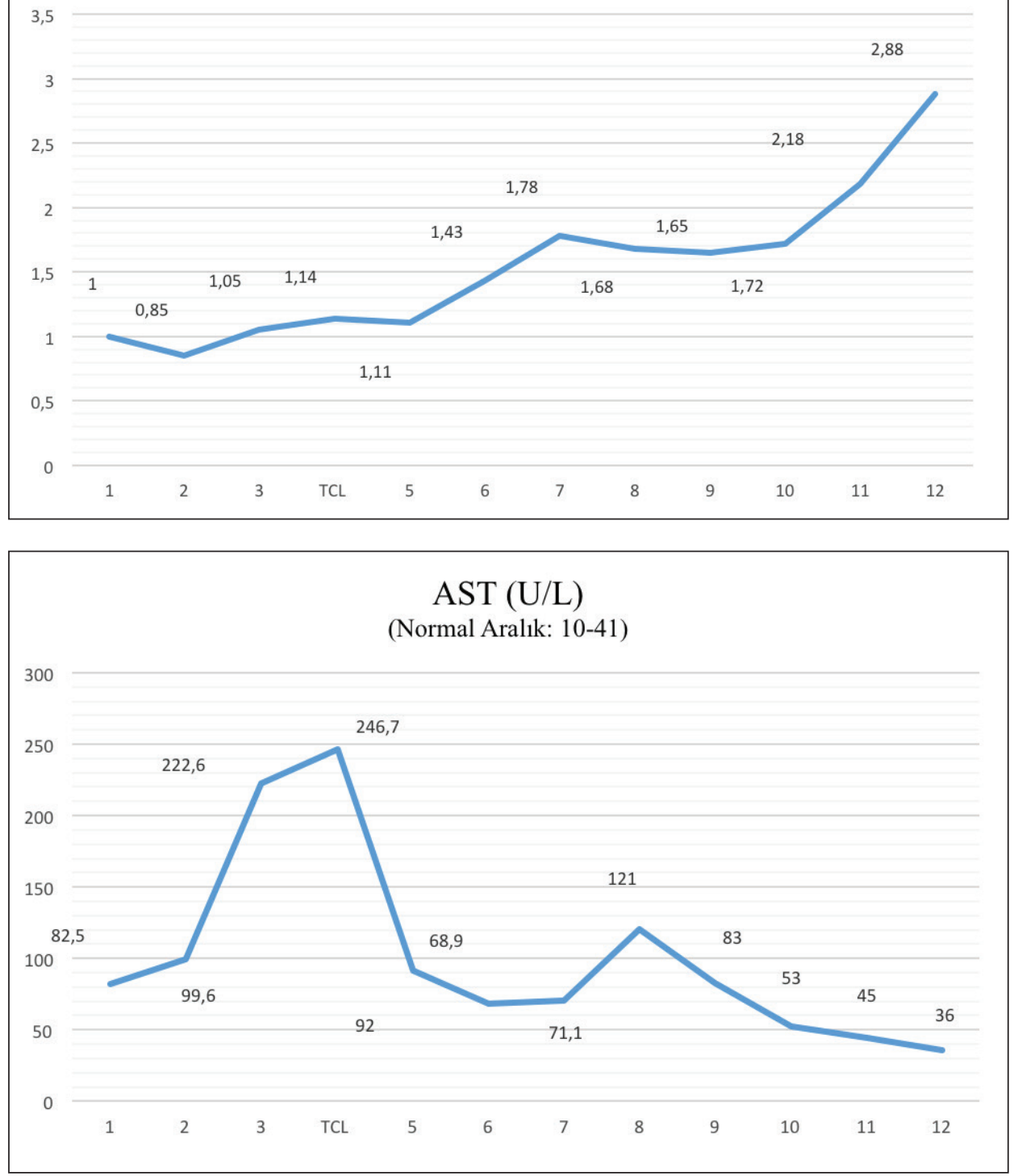

Grafik 1: TGL öncesi ve sonrasında D-dimer laboratuvar değerlerinin değişimi.
Grafik 2: TCL öncesi ve sonrasinda Lenfosit laboratuvar değerlerinin değişimi.

Grafik 3: TCL öncesi ve sonrasında AST laboratuvar değerlerinin değişimi. 

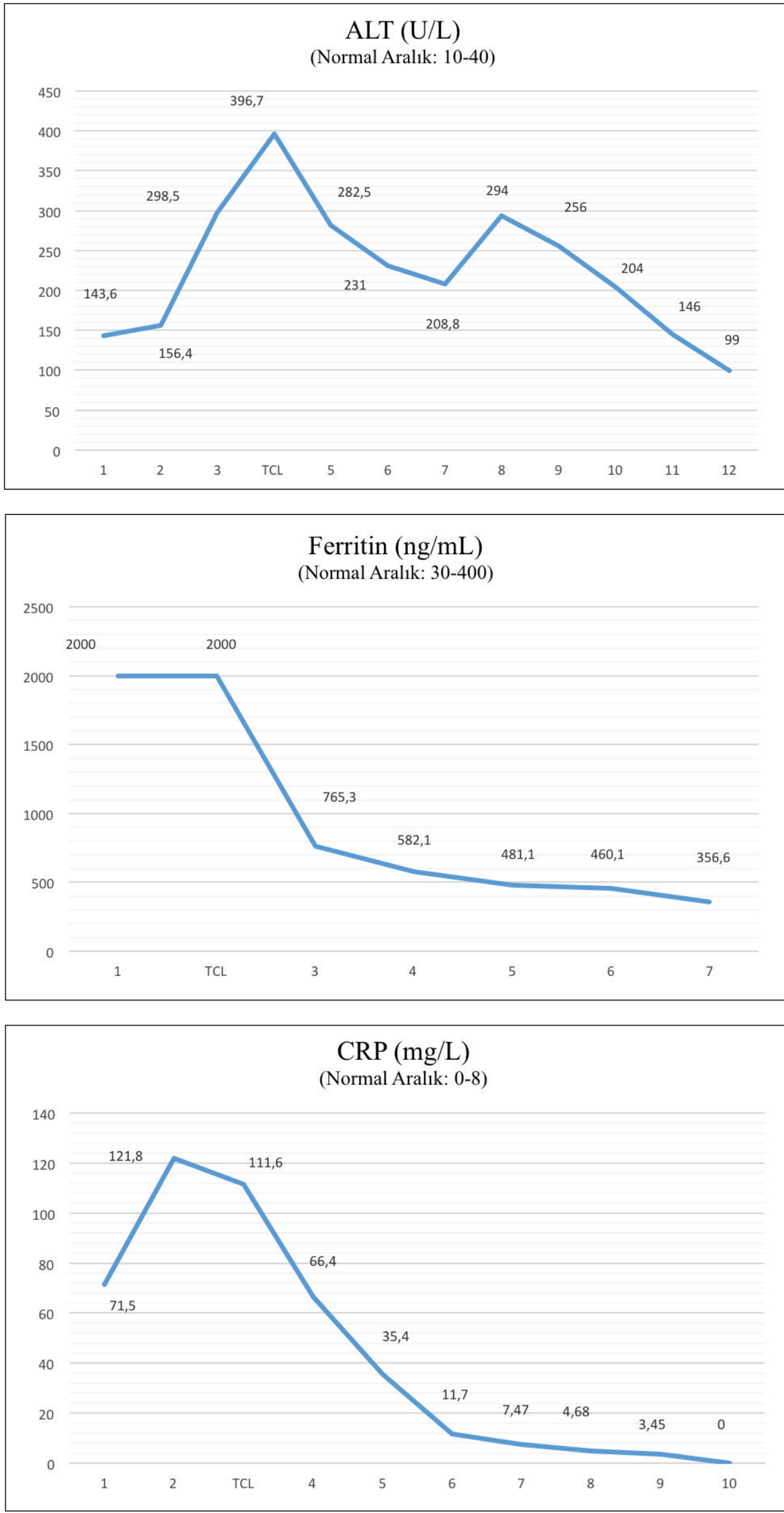

Grafik 4: TCL öncesi ve sonrasında ALT laboratuvar değerlerinin değişimi.

Grafik 5: TCL öncesi ve sonrasinda Ferritin laboratuvar değerlerinin değişimi.

Grafik 6: TCL öncesi ve sonrasinda CRP laboratuvar değerlerinin değişimi. 
rinde klinik, laboratuvar ve görüntüleme olarak iyileşme olduğu görüldü. Bu tek vakalık deneyimimiz ve yapılan çalışmalar MAS tanısının erken konulması ve tedavinin buna göre düzenlenmesinin mortaliteye katkı sağlayacağını düşündürmüştür. Tocilizumab tedavisinin sitokin firtınasını baskılayarak oluşacak akciğer hasarının önüne geçtiği ve hastanın entübasyon ihtimalini azalttı̆̆ını düşündürmüştür. Kendi vakamızda gerek laboratuvar tetkiklerin takipleri, gerek görüntülemedeki patolojinin gerilemesi bu düşüncemizi desteklemektedir. Bu düşüncemizi kanıtlamak için ileri çalışmalara ihtiyaç vardır.

\section{KAYNAKLAR}

1. Guan WJ, Ni ZY, Hu Y, Liang WH, Ou CQ, He JX, Liu L, Shan H, Lei CL, Hui DSC, Du B, Li LJ, Zeng G, Yuen KY, Chen RC, Tang CL, Wang T, Chen PY, Xiang J, Li SY, Wang JL, Liang ZJ, Peng YX, Wei L, Liu Y, Hu YH, Peng P, Wang JM, Liu JY, Chen Z, Li G, Zheng ZJ, Qiu SQ, Luo J, Ye CJ, Zhu SY, Zhong NS. Clinical Characteristics of Coronavirus Disease 2019 in China.; China Medical Treatment Expert Group for Covid-19. N Engl J Med. 2020;382(18):1708-1720. doi: 10.1056/ NEJMoa2002032.

2. Crayne CB, Albeituni S, Nichols KE, Cron RQ. The immunology of macrophage activation syndrome. Front Immunol. 2019;10:1 19. doi: 10.3389/fimmu.2019.00119.

3. Carter SJ, Tattersall RS, Ramanan AV. Macrophage activation syndrome in adults: recent advances in pathophysiology, diagnosis and treatment. Rheumatology (Oxford). 2019;58(1):5-17. doi: 10.1093/rheumatology/ key006.

4. Xu Z, Shi L, Wang Y, Zhang J, Huang L, Zhang C, Liu S, Zhao P, Liu H, Zhu L, Tai Y, Bai C, Gao T, Song J, Xia P, Dong J, Zhao J, Wang FS. Pathological findings of COVID-19 associated with acute respiratory distress syndrome. Lancet Respir Med. 2020;8(4):420-422. doi: 10.1016/S2213-2600(20)30076-X.

5. Jamilloux Y, Henry T, Belot A, Viel S, Fauter M, Jammal TE, Walzer T, François B, Sève P. Should we stimulate or suppress immune responses in COVID-19? Cytokine and anti-cytokine interventions. Autoimmun Rev. 2020; 19(7): 102567. doi: $10.1016 /$ j.autrev.2020.102567

6. Yao XH, Li TY, He ZC, Ping YF, Liu HW, Yu SC, Mou HM, Wang LH, Zhang HR, Fu WJ, Luo T, Liu F, Chen C, Xiao HL, Guo HT, Lin S, Xiang DF, Shi Y, Li QR, Huang X, Gui Y, Li XZ, Tang W, Pan PF, Huang XQ, Ding YQ, Bian XW. A pathological report of three COVID-19 cases by minimally invasive autopsies. Zhonghua Bing Li Xue Za Zhi 2020;49(5):41 1-417.

7. Tisoncik JR, Korth MJ, Simmons CP, Farrar J, Martin TR, Katze MG. Into the eye of the cytokine storm. Microbiol Mol Biol Rev 2012;76:16-32.

\section{ONAY}

Yazarlar arasında herhangi bir çıkar çatışması mevcut değildir. Çalışmamız Osmaniye Devlet Hastanesi'nde takip edilen hastamızın retrospektif verileri ile yapılmış olup, kurumsal ve finansal destek mevcut değildir. Veri ve görüntülerin kullanımında vakadan aydınlatılmış onam alınmıştır.

8. Meduri GU, Headley S, Kohler G, Stentz F, Tolley E, Umberger R, Leeper K. Persistent elevation of inflammatory cytokines predicts a poor outcome in ARDS: plasma IL-1 $\beta$ and IL-6 levels are consistent and efficient predictors of outcome over time. Chest. 1995;107(4):106273.

9. Chen G, Wu D, Guo W, Cao Y, Huang D, Wang H, Wang T, Zhang X, Chen H, Yu H, Zhang X, Zhang M, Wu S, Song J, Chen T, Han M, Li S, Luo X, Zhao J, Ning Q. Clinical and immunologic features in severe and moderate forms of Coronavirus Disease 2019. J Clin Invest. 2020;130(5):2620-2629. doi: 10.1172/JCI137244.

10. Chen W, Lan Y, Yuan X, Deng X, Li Y, Cai X, Li L, He R, Tan Y, Deng X, Gao M, Tang G, Zhao L, Wang J, Fan Q, Wen C, Tong Y, Tang Y, Hu F, Li F, Tang X. Detectable 2019-nCoV viral RNA in blood is a strong indicator for the further clinical severity. Emerg Microbes Infect. 2020;9(1):469-473. doi: 10.1080/22221751.2020.1732837.

11. Bilimsel Danışma Kurulu Çalışması. T.C Sağlık Bakanlığı Halk Sağlığı Genel Müdürlüğü, COVID-19 (SARSCov2-Enfeksiyonu) Antisitokin-Antinflamatuar Tedaviler, Koagülopati Yönetimi, 1 Haziran 2020, Ankara.

12. Martin Sheppard, Faidra Laskou, Philip P. Stapleton, Shahryar Hadavi, and Bhaskar Dasgupta. Tocilizumab (Actemra). Human Vaccines \& Immunotherapoutics 2017;13(9):1972-1988.

13. Higuchi T, Nakanishi T, Takada K, Matsumoto M, Okada M, Horikoshi H, Suzuki K. A Case of Multicentric Castleman's Disease Having Lung Lesion Successfully Treated with Humanized Anti-interleukin-6 Receptor Antibody, Tocilizumab. Immunology, Allergic Disorders \& Rheumatology. J Korean Med Sci 2010; 25: 1364-1367.

14. Srirangan S, Choy EH. The role of interleukin 6 in the patho- physiology of rheumatoid arthritis. Ther $\mathrm{Adv}$ Musculoskelet Dis 2010; 2(5):247-56.

15. Zhang X, Song K, Tong F, Fei M, Guo H, Lu Z, Wang J, Zheng C. First case of COVID-19 in a patient with multiple myeloma successfully treated with tocilizumab, Blood Adv. 2020; 4(7): 1307-10. 
16. Michot JM, Albiges L, Chaput N, Saada V, Pommeret F, Griscelli F, Balleyguier C, Besse B, Marabelle A, Netzer F, Merad M, Robert C, Barlesi F, Gachot B, Stoclin A. Tocilizumab, an anti-IL6 receptor antibody, to treat Covid-19-related respiratory failure: a case report, Ann. Oncol. 2020; 31(7): 961-64.

17. Weiss P, Murdoch DR. Lancet. Clinical course and mortality risk of severe COVID-19. 2020;395(10229):10141015. doi: 10.1016/S0140-6736(20)30633-4.
18. Zhou F, Yu T, Du R, Fan G, Liu Y, Liu Z, Xiang J, Wang Y, Song B, Gu X, Guan L, Wei Y, Li H, Wu X, Xu J, Tu S, Zhang Y, Chen H, Cao B. Clinical course and risk factors for mortality of adult inpatients with COVID-19 in Wuhan, China: a retrospective cohort study. Lancet. 2020;395(10229):1054-1062. doi: 10.1016/S01406736(20)30566-3. 